\title{
Continuity of the North Qilian and North Qinling orogenic belts, Central Orogenic System of China: Evidence from newly discovered Paleozoic adakitic rocks
}

\author{
Chien-Yuan Tseng a , Huai-Jen Yang a,*, Houng-Yi Yang a, Dunyi Liu ${ }^{\mathrm{b}}$, Cailai Wu ${ }^{\mathrm{c}}$, Chiu-Kuang Cheng ${ }^{\mathrm{d}}$, \\ Cheng-Hong Chen ${ }^{\mathrm{d}}$, Choon-Muar Ker ${ }^{\mathrm{a}}$ \\ a Department of Earth Sciences, National Cheng-Kung University, Tainan, Taiwan, ROC \\ ${ }^{\mathrm{b}}$ Beijing SHRIMP Centre, Institute of Geology, Chinese Academy of Geological Sciences, Beijing, China \\ ' Institute of Geology, Chinese Academy of Geological Sciences, Beijing, China \\ d Department of Geosciences, National Taiwan University, Taipei, Taiwan, ROC
}

\section{A R T I C L E I N F O}

\section{Article history:}

Received 29 October 2008

Received in revised form 21 March 2009

Accepted 8 April 2009

Available online 16 April 2009

\section{Keywords:}

Adakite

Qilian

Qinling

Orogenic belt

Lower crust

Tethyan

\begin{abstract}
A B S T R A C T
Adakitic intrusive rocks of $\sim 430-450$ Ma were discovered in the North Qilian orogenic belt, the western section of the Central Orogenic System (COS) in China. These adakitic rocks were lower crust melts rather than slab melts as indicated by their crustal $\mathrm{Ce} / \mathrm{Pb}, \mathrm{Nb} / \mathrm{U}, \mathrm{Ti} / \mathrm{Eu}$, and $\mathrm{Nd} / \mathrm{Sm}$ ratios and radiogenically enriched $\left({ }^{87} \mathrm{Sr} /{ }^{86} \mathrm{Sr}\right)_{\mathrm{i}}$ of $0.7053-0.7066$ and $\varepsilon_{\mathrm{Nd}}(t)$ of -0.9 to -1.7 . While they are all characterized by low $\mathrm{Yb}$ $(<1.1 \mathrm{ppm})$ and $\mathrm{Y}(<11.5 \mathrm{ppm})$ abundances with high $\mathrm{Sr} / \mathrm{Y}(>65)$ and $(\mathrm{La} / \mathrm{Yb})_{\mathrm{N}}(>13.7)$ ratios, these adakitic rocks are classified into the low-MgO-Ni-Cr and high-MgO-Ni-Cr groups. The low-MgO samples were derived from partial melting of thickened lower crust, whereas the high-MgO samples were melts from delaminated lower crust, which subsequently interacted with mantle peridotite upon ascent. Adakitic rocks from the adjacent North Qinling orogenic belt also originated from thickened lower crust at $\sim 430 \mathrm{Ma}$. In addition, the North Qilian and North Qinling orogenic belts both consist of lithological assemblages varying from subduction-accretionary complexes at south to central arc assemblages, which include adakitic rocks, then to backarc phases at north. Such a sequence reflects northward subduction of the Qilian and Qinling oceans. In these two orogenic belts, the occurrence of adakitic rocks of common origin and ages together with the similarities in tectonic configurations and lithological assemblages are considered to be the evidence for the continuity between eastern Qilian and western Qinling, forming a >1000 km Early Paleozoic orogenic belt. In such a tectonic configuration, the Qilian and Qinling oceans that subducted from south possibly represent parts of the large "Proto-Tethyan Ocean". This inference is supported by the coexistence of Early Paleozoic coral and trilobite specimens from Asia, America and Australia in the North Qilian orogenic belt. Post-400 Ma volcanic rocks occur in the North Qinling orogenic belt but are absent in the North Qilian orogenic belt, indicating that these two orogenic belts underwent distinct evolution history after the closure of the Proto-Tethyan Ocean ( 420 Ma).
\end{abstract}

(C) 2009 International Association for Gondwana Research. Published by Elsevier B.V. All rights reserved.

\section{Introduction}

China is tectonically composed of the South China block and Tibet Plateau on the south and the North China and Tarim blocks on the north (Fig. 1a). Between these northern and southern tectonic units is the WNW trending Central Orogenic System (COS) extending from the eastern Sulu through Dabie, Tongbai, Qinling, and Qilian to the western Kunlun orogenic belts (Fig. 1a; Yang et al., 2003). The relationships between these orogenic belts provide critical constraints for reconstructing the tectonic evolution of eastern Asia and the

\footnotetext{
* Corresponding author. Department of Earth Sciences, National Cheng-Kung University, Tainan, Taiwan 70101, ROC. Tel.: +886 6 2757575x65429; fax: +886 6 2740285.

E-mail address: hjyang@mail.ncku.edu.tw (H.-J. Yang).
}

Gondwana continent (e.g., Metcalfe, 2006; Han et al., 2009). The tectonic framework of the Sulu and Dabie orogenic belts is well established on the wide occurrence of ultrahigh pressure eclogites and gneisses resulted from the collision between the North and South China blocks at $\sim 220 \mathrm{Ma}$ (e.g., Ayers et al., 2002; Katsube et al., 2009; Zhang et al., 2009). Based on SHRIMP zircon ages and tectonostratigraphy, Zhai et al. (2007) extended the Sulu-Dabie orogenic belt to the Korean Peninsula. In contrast, tectonic models for the western COS are mostly limited to individual orogenic belts (e.g., Ratschbacher et al., 2003; Wang et al., 2003; Li et al., 2007; Ye et al., 2008). An important result is that the Kunlun and Qilian orogenic belts represent a suture zone from the closure of the "Proto-Tethyan Ocean" (Bian et al., 2004; Tung et al., 2007). However, the eastern extension of this suture zone remains unclear due to insufficient geological, petrological and geochronological constraints on the relationships between 

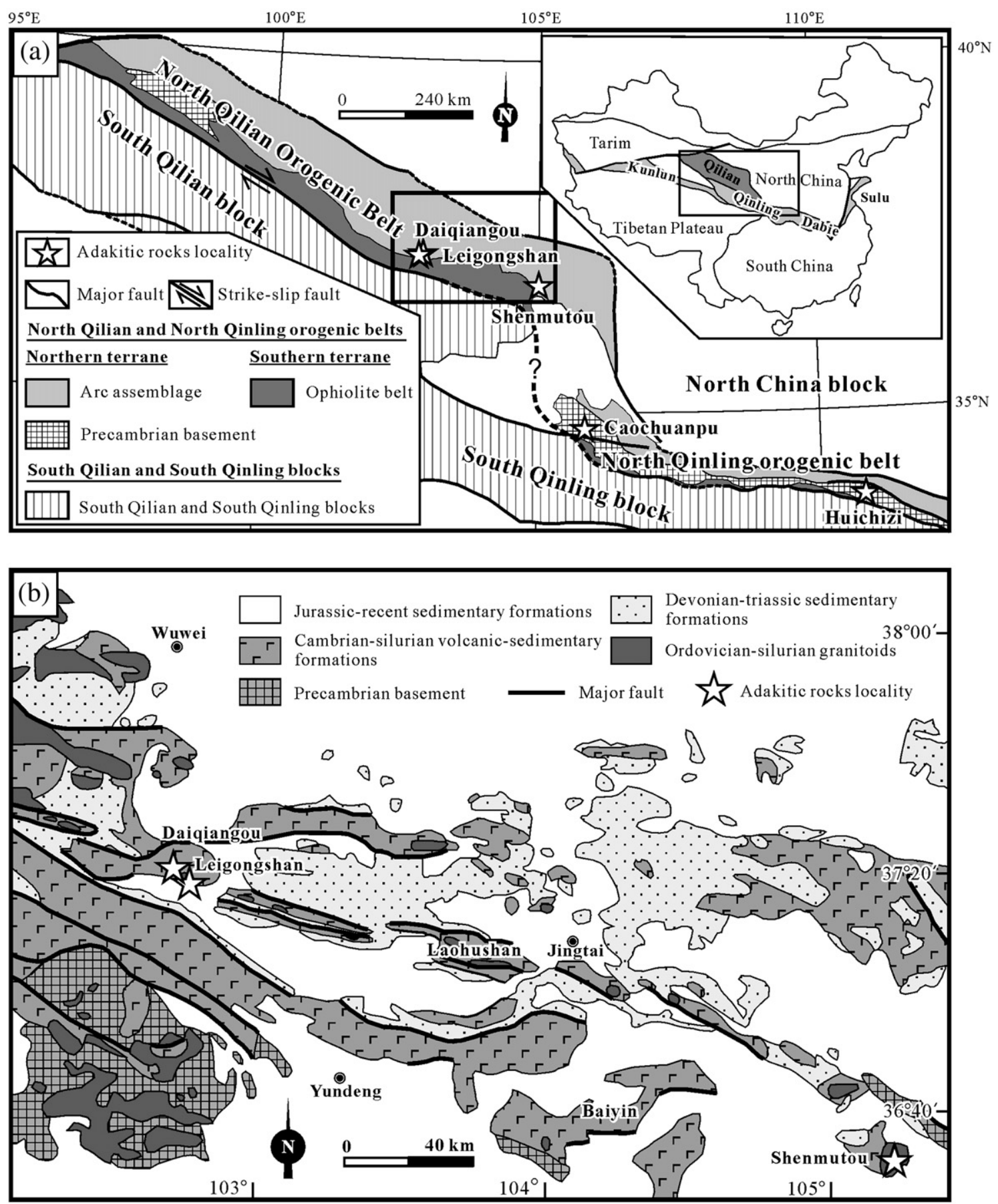

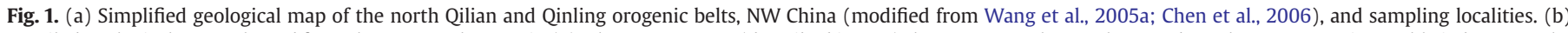

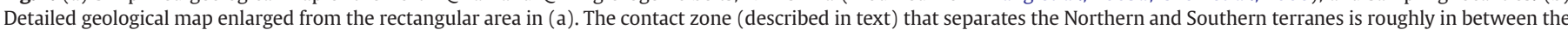
Precambrian-Paleozoic contact at the south and the Leigonshan-Laohushan-Shenmutou lineament at north.

these western orogenic belts, hindering the development of an integrated tectonic model.

In this paper we identify adakitic rocks from the North Qilian orogenic belt and propose that they are petrogenetically and geochronologically related to the adakitic rocks from the easterly adjacent North Qinling orogenic belt. This result together with similarities in tectonic configurations and major constituent lithological assemblages leads to an interpretation that the North Qilian and North Qinling orogenic belts were an undivided tectonic unit formed by the northward subduction of the "Proto-Tethyan Ocean" during Early Paleozoic time.

\section{Geological setting}

The Qilian Mountain System forms a $300 \mathrm{~km}$ wide and $\sim 1200 \mathrm{~km}$ long WNW-trending belt at the northern margin of the Tibetan Plateau (Fig. 1a). It is composed of the North Qilian orogenic belt and the South Qilian block (Fig. 1a). The South Qilian block consists of Precambrian basement overlain by Paleozoic sedimentary sequence (Song et al., 2006). The North Qilian orogenic belt has been proposed to be an island arc system formed by northward subduction of an ancient ocean, the Paleo-Qilian ocean (Xu et al., 1994; Yang et al., 2002). Its eastern section, which bounds to the western end of the 
Qinling orogenic belt with an ambiguous tectonic relationship (Fig. 1a), is divided into the Northern and Southern terranes by a $<10 \mathrm{~km}$ wide contact zone (Fig. 1b; Yang et al., 2002; Wang et al., 2005a). The Southern terrane represents the remnant of oceanic lithosphere, whereas the Northern terrane is composed of arc assemblages (Yang et al., 2002). The contact zone consists mainly of Early Paleozoic volcanic and sedimentary assemblages, which underwent epidote-amphibolite facies metamorphism (Yang et al., 2002). The studied samples were collected from three felsic intrusive bodies at the east of the Northern terrane (Fig. 1b). Among them, the Shenmutou outcrop is the largest with an area of $\sim 50 \mathrm{~km}^{2}$, whereas the Leigongshan and Daiqiangou outcrops are $<10 \mathrm{~km}^{2}$. These outcrops are lithologically homogeneous without obvious mineral layering.

\section{Sample descriptions}

Samples were collected from Daiqiangou, Leigongshan, and Shenmutou along the Laohushan range (Fig. 1b). All the rocks are coarse-grained. The Daiqiangou and Leigongshan samples are tonalites, consisting of $40-50 \%$ quartz and $60-50 \%$ plagioclase. The plagioclase grains $\left(\mathrm{An}_{33-42}\right)$ are euhedral and slightly saussuritized.
The Shenmutou samples contain 20-30\% quartz, 40-30\% alkali feldspar and 40-30\% plagioclase; therefore, are classified as quartz monzonite. The plagioclase $\left(\mathrm{An}_{13-18}\right)$ is euhedral to subhedral and is commonly zoned. The alkali feldspar is perthite. In all samples, rounded quartz grains mostly occur as an interstitial phase. Accessory minerals, including hornblende, biotite, titanomagnetite and ilmenite, are $<10 \%$. Epidote, chlorite, titanite and prehnite occur as secondary minerals. The slightly uralitized hornblende grains are euhedralsubhedral, containing small inclusions of quartz and plagioclase. The biotite has Mg\# of 60-62 and is commonly replaced by chlorite and prehnite. The rim of titanomagnetite is sometimes altered to titanite and chlorite. Samples were analyzed for bulk major and trace element abundances (Table 1) and $\mathrm{Sr}$ and $\mathrm{Nd}$ isotope ratios (Table 2). In addition, zircon grains in two samples were separated for $\mathrm{U}-\mathrm{Pb}$ age determination (Table 3).

\section{Analytical methods}

\subsection{Bulk major and trace element abundances}

Major element concentrations were determined by X-ray fluorescence (XRF). Abundances of trace elements were measured by

Table 1

Major and trace element abundances for Qilian adakitic rocks.

\begin{tabular}{|c|c|c|c|c|c|c|c|c|c|}
\hline Sample & SMT-01 & SMT-02 & SMT-05 & SMT-07 & SMT-12 & LGS-07 & LGS-10 & LGS-15 & D38 \\
\hline \multicolumn{10}{|c|}{ Major element concentrations in wt.\% } \\
\hline $\mathrm{SiO}_{2}$ & 66.20 & 67.40 & 66.88 & 66.39 & 68.38 & 62.59 & 63.51 & 64.19 & 65.57 \\
\hline $\mathrm{TiO}_{2}$ & 0.38 & 0.40 & 0.40 & 0.36 & 0.31 & 0.35 & 0.40 & 0.28 & 0.32 \\
\hline $\mathrm{Al}_{2} \mathrm{O}_{3}$ & 16.25 & 16.26 & 16.28 & 16.12 & 15.89 & 17.06 & 17.23 & 17.91 & 17.11 \\
\hline $\mathrm{FeO}^{\mathrm{t}}$ & 2.75 & 2.58 & 2.99 & 2.83 & 2.37 & 4.23 & 4.55 & 4.20 & 3.90 \\
\hline $\mathrm{MnO}$ & 0.05 & 0.05 & 0.05 & 0.05 & 0.04 & 0.07 & 0.09 & 0.07 & 0.10 \\
\hline $\mathrm{MgO}$ & 2.15 & 2.30 & 2.32 & 2.01 & 1.87 & 1.50 & 1.72 & 1.36 & 1.55 \\
\hline $\mathrm{CaO}$ & 2.52 & 3.79 & 3.56 & 3.87 & 3.46 & 4.90 & 6.46 & 4.47 & 5.92 \\
\hline $\mathrm{Na}_{2} \mathrm{O}$ & 5.65 & 4.96 & 4.64 & 5.09 & 4.96 & 3.12 & 3.16 & 2.66 & 3.45 \\
\hline $\mathrm{K}_{2} \mathrm{O}$ & 2.46 & 1.99 & 1.95 & 1.80 & 1.88 & 1.37 & 1.21 & 1.42 & 1.06 \\
\hline $\mathrm{P}_{2} \mathrm{O}_{5}$ & 0.18 & 0.18 & 0.19 & 0.18 & 0.16 & 0.10 & 0.12 & 0.11 & 0.10 \\
\hline Total & 98.59 & 99.92 & 99.27 & 98.70 & 99.32 & 95.30 & 98.45 & 96.66 & 99.07 \\
\hline L.O.I. & & & 0.67 & & & 3.21 & & 2.61 & \\
\hline \multicolumn{10}{|c|}{ Trace element concentrations in ppm } \\
\hline $\mathrm{Ni}$ & 38 & 39 & 43 & 39 & 35 & 11 & 3 & 20 & 8 \\
\hline $\mathrm{Cr}$ & 51 & 54 & 77 & 52 & 42 & 25 & 9 & 40 & 9 \\
\hline V & 58 & 69 & 68 & 66 & 55 & 91 & 97 & 86 & 82 \\
\hline $\mathrm{Ba}$ & 974 & 826 & 735 & 809 & 715 & 713 & 776 & 841 & 801 \\
\hline $\mathrm{Rb}$ & 84.7 & 55.2 & 58.9 & 51.7 & 53.1 & 47.9 & 41 & 62.6 & 34.9 \\
\hline $\mathrm{Sr}$ & 696 & 756 & 713 & 766 & 685 & 654 & 735 & 745 & 772 \\
\hline $\mathrm{Zr}$ & 114 & 92 & 96 & 116 & 81 & 47 & 74 & 61 & 54 \\
\hline Y & 8.78 & 11.31 & 7.61 & 7.73 & 6.79 & 5.69 & 6.95 & 8.64 & 6.20 \\
\hline $\mathrm{Nb}$ & 6.61 & 9.00 & 6.04 & 5.55 & 5.35 & 2.00 & 2.47 & 2.90 & 2.43 \\
\hline Cs & 1.93 & 2.97 & 2.57 & 3.05 & 2.31 & 2.54 & 2.33 & 1.91 & 1.00 \\
\hline Sc & 8.5 & 8.9 & 8.8 & 7.3 & 6.4 & 8.9 & 10.0 & 9.4 & 9.1 \\
\hline Hf & 2.50 & 2.59 & 2.65 & 2.24 & 2.39 & 1.37 & 1.41 & 1.65 & 1.69 \\
\hline Та & 1.68 & 0.76 & 0.37 & 0.71 & 0.35 & 0.10 & 1.04 & 0.16 & 0.15 \\
\hline $\mathrm{Pb}$ & 15.0 & 16.7 & 16.1 & 15.2 & 17.6 & 15.9 & 15.7 & 6.94 & 14.5 \\
\hline Th & 8.64 & 11.0 & 9.90 & 8.41 & 9.02 & 2.49 & 6.30 & 8.28 & 12.5 \\
\hline $\mathrm{U}$ & 1.57 & 1.69 & 1.71 & 1.20 & 1.26 & 1.32 & 2.18 & 3.18 & 1.77 \\
\hline $\mathrm{La}$ & 23.7 & 28.6 & 22.4 & 16.6 & 17.1 & 9.83 & 18.1 & 25.5 & 30.6 \\
\hline $\mathrm{Ce}$ & 41.6 & 68.3 & 52.2 & 43.7 & 31.3 & 17.2 & 30.8 & 43.8 & 48.8 \\
\hline $\operatorname{Pr}$ & 4.38 & 6.25 & 5.05 & 3.71 & 3.39 & 2.04 & 3.23 & 4.63 & 4.67 \\
\hline $\mathrm{Nd}$ & 16.3 & 23.5 & 17.6 & 13.9 & 12.9 & 8.1 & 12.4 & 15.7 & 16.0 \\
\hline $\mathrm{Sm}$ & 2.90 & 4.36 & 2.89 & 2.53 & 2.51 & 1.77 & 2.43 & 2.61 & 2.55 \\
\hline $\mathrm{Eu}$ & 0.84 & 1.08 & 0.82 & 0.75 & 0.77 & 0.60 & 0.72 & 0.72 & 0.73 \\
\hline Gd & 2.28 & 3.15 & 2.18 & 1.94 & 1.91 & 1.44 & 1.84 & 1.88 & 1.76 \\
\hline $\mathrm{Tb}$ & 0.30 & 0.43 & 0.29 & 0.28 & 0.25 & 0.20 & 0.24 & 0.26 & 0.22 \\
\hline Dy & 1.66 & 2.24 & 1.54 & 1.40 & 1.35 & 1.05 & 1.37 & 1.55 & 1.15 \\
\hline Ho & 0.30 & 0.41 & 0.28 & 0.27 & 0.26 & 0.21 & 0.26 & 0.32 & 0.22 \\
\hline Er & 0.77 & 1.06 & 0.75 & 0.72 & 0.69 & 0.60 & 0.67 & 0.90 & 0.57 \\
\hline $\mathrm{Tm}$ & 0.12 & 0.15 & 0.11 & 0.10 & 0.09 & 0.09 & 0.10 & 0.14 & 0.08 \\
\hline $\mathrm{Yb}$ & 0.68 & 0.90 & 0.65 & 0.60 & 0.60 & 0.63 & 0.63 & 0.98 & 0.55 \\
\hline Lu & 0.11 & 0.14 & 0.11 & 0.10 & 0.10 & 0.11 & 0.10 & 0.16 & 0.09 \\
\hline
\end{tabular}

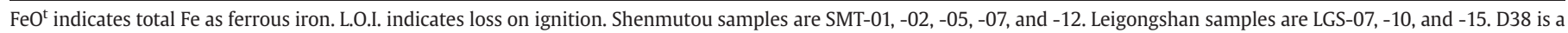
Daiqiangou sample. 
Table 2

$\mathrm{Sr}$ and Nd isotopic data for the Qilian adakitic rocks.

\begin{tabular}{|c|c|c|c|c|c|c|c|c|c|c|}
\hline Sample & ${ }^{87} \mathrm{Rb} /{ }^{86} \mathrm{Sr}$ & ${ }^{87} \mathrm{Sr} /{ }^{86} \mathrm{Sr}$ & $\pm 2 \sigma$ & $\left({ }^{87} \mathrm{Sr} /{ }^{86} \mathrm{Sr}\right)_{\mathrm{i}}$ & ${ }^{147} \mathrm{Sm} /{ }^{144} \mathrm{Nd}$ & ${ }^{143} \mathrm{Nd} /{ }^{144} \mathrm{Nd}$ & $\pm 2 \sigma$ & $\varepsilon_{\mathrm{Nd}}(t)$ & $\varepsilon_{\mathrm{Nd}}(0)$ & $\overline{T_{\mathrm{DM}}(\mathrm{Ga})}$ \\
\hline \multicolumn{11}{|c|}{ Quartz monzodiorites from Shenmutou ( $t=430 \mathrm{Ma})$} \\
\hline SMT-05 & 0.239 & 0.706924 & 11 & 0.705460 & 0.099 & 0.512277 & 12 & -1.7 & -7.0 & 1.16 \\
\hline SMT-07 & 0.195 & 0.706695 & 12 & 0.705499 & 0.110 & 0.512297 & 11 & -1.9 & -6.7 & 1.25 \\
\hline \multicolumn{11}{|c|}{ Tonalites from Leigongshan $(t=453 \mathrm{Ma})$} \\
\hline LGS-07 & 0.212 & 0.707771 & 11 & 0.706403 & 0.132 & 0.512349 & 13 & -1.9 & -5.6 & 1.49 \\
\hline LGS-10 & 0.161 & 0.707607 & 14 & 0.706565 & 0.118 & 0.512332 & 12 & -1.4 & -6.0 & 1.31 \\
\hline LGS-15 & 0.243 & 0.708335 & 10 & 0.706766 & 0.101 & 0.512257 & 12 & -1.9 & -7.4 & 1.20 \\
\hline
\end{tabular}

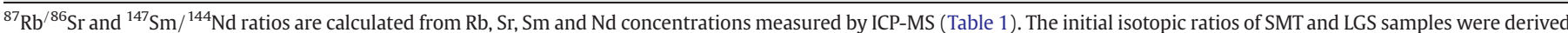

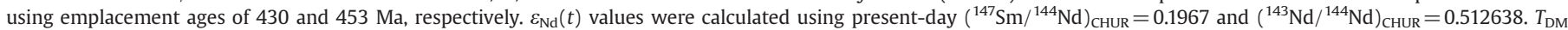
values were calculated using present-day $\left({ }^{147} \mathrm{Sm} /{ }^{144} \mathrm{Nd}\right)_{\mathrm{DM}}=0.2137$ and $\left({ }^{143} \mathrm{Nd} /{ }^{144} \mathrm{Nd}\right)_{\mathrm{DM}}=0.51315$.

inductively-coupled plasma mass spectrometry (ICP-MS), except for $\mathrm{Ni}, \mathrm{Cr}$ and $\mathrm{V}$ concentrations, which were analyzed by XRF. All analyses were carried out at the Washington State University, U.S.A. following the procedures of Johnson et al. (1999). The accuracy and precision are $<1 \%$ for XRF analysis and $~ 5 \%$ for ICP-MS analysis.

\section{2. $\mathrm{Sr}$ and $\mathrm{Nd}$ isotope analyses}

For $\mathrm{Sr}$ and $\mathrm{Nd}$ isotopic analyses, approximately $70 \mathrm{mg}$ of sample powder was decomposed by $\mathrm{HF}-\mathrm{HNO}_{3}$ mixture. After dryness, samples were re-dissolved in $2 \mathrm{ml} \mathrm{HCl}(2 \mathrm{~N})$, then, loaded onto the column containing AG50W-X8 resin (100-200 mesh) to separate $\mathrm{Sr}$ and REE. The Sr aliquot was purified by eluting through the Sr-Spec resin. The REE fraction was passed through Eichrom Ln resin to extract Nd. Approximately $250 \mathrm{ng}$ of $\mathrm{Sr}$ and 50-200 ng Nd were loaded onto double filaments (Re-Ta), and measured by Thermal Ionization Mass Spectrometer (TIMS; Finnigan MAT262 at National Cheng-Kung University). The total procedural blanks for $\mathrm{Sr}$ and $\mathrm{Nd}$ were both
$<200$ pg. Mass fractionations were corrected using ${ }^{146} \mathrm{Nd} /$ ${ }^{144} \mathrm{Nd}=0.7219$ and ${ }^{86} \mathrm{Sr} /{ }^{88} \mathrm{Sr}=0.1194$. During the course of this study, the mean ${ }^{87} \mathrm{Sr} /{ }^{86} \mathrm{Sr}$ ratio was $0.710245 \pm 11(n=10)$ for NBS 987 and $0.705011 \pm 12(n=12)$ for BCR-1, whereas the mean ${ }^{143} \mathrm{Nd} /$ ${ }^{144} \mathrm{Nd}$ ratios for LaJolla and BCR-1 were $0.511855 \pm 12(n=12)$ and $0.512625 \pm 24(n=7)$, respectively.

\subsection{Zircon SHRIMP $U-P b$ dating}

Two samples, SMT-05 and LGS-07 were crushed and sieved. Zircon grains were separated by heavy liquids and magnetic separator and finally purified by hand-picking. They were mounted with epoxy and ground to half of their original grain sizes then polished. Reflectedlight and transmitted-light photomicrographs and cathodoluminescence images show that most zircon grains are euhedral with long axis of $80-200 \mu \mathrm{m}$ and aspect ratios of $2-3$. The separated zircon grains were dated using in-situ U-Pb isotope data obtained from SHRIMP II at Beijing SHRIMP Centre (Williams, 1998). Radiogenic lead

Table 3

U-Th-Pb SHRIMP data for zircon in two Qilian adakitic rocks.

\begin{tabular}{|c|c|c|c|c|c|c|c|c|c|c|}
\hline Spot & $\mathrm{U}(\mathrm{ppm})$ & Th (ppm) & ${ }^{232} \mathrm{Th} /{ }^{238} \mathrm{U}$ & ${ }^{206} \mathrm{~Pb}^{*}(\mathrm{ppm})$ & Common $\mathrm{Pb}(\%)$ & ${ }^{206} \mathrm{~Pb} * /{ }^{238} \mathrm{U}$ & $\pm \%$ & ${ }^{207} \mathrm{~Pb} * /{ }^{206} \mathrm{~Pb}^{*}$ & $\pm \%$ & ${ }^{206} \mathrm{~Pb} * /{ }^{238} \mathrm{U}$ age $(\mathrm{Ma})$ \\
\hline \multicolumn{11}{|c|}{ Quartz monzodiorite from Shenmutou } \\
\hline SMT-1 & 287 & 145 & 0.52 & 16.9 & 0.64 & 0.0681 & 2.1 & 0.0502 & 2.4 & $424.4 \pm 8.6$ \\
\hline SMT-2 & 345 & 188 & 0.56 & 19.8 & 0.17 & 0.0666 & 2.1 & 0.0549 & 1.4 & $415.4 \pm 8.3$ \\
\hline SMT-3 & 269 & 114 & 0.44 & 16.5 & 0.15 & 0.0711 & 2.1 & 0.0556 & 2.5 & $442.6 \pm 8.9$ \\
\hline SMT-4 & 436 & 275 & 0.65 & 26.3 & 0.34 & 0.0700 & 2.1 & 0.0523 & 1.9 & $436.3 \pm 8.9$ \\
\hline SMT-5 & 288 & 171 & 0.61 & 17.6 & 0.70 & 0.0709 & 2.1 & 0.0507 & 3.5 & $441.6 \pm 8.9$ \\
\hline SMT-6 & 346 & 189 & 0.56 & 19.8 & 0.66 & 0.0663 & 2.1 & 0.0540 & 2.9 & $413.8 \pm 8.3$ \\
\hline SMT-7 & 387 & 173 & 0.46 & 22.7 & 0.37 & 0.0680 & 2.2 & 0.0538 & 2.4 & $423.9 \pm 8.9$ \\
\hline SMT-8 & 371 & 235 & 0.65 & 22.1 & 0.32 & 0.0692 & 2.1 & 0.0526 & 2.6 & $431.4 \pm 8.9$ \\
\hline SMT-9 & 473 & 245 & 0.53 & 28.9 & 0.23 & 0.0710 & 2.0 & 0.0542 & 1.6 & $442.3 \pm 8.7$ \\
\hline SMT-10 & 342 & 233 & 0.70 & 20.2 & 0.75 & 0.0681 & 2.1 & 0.0519 & 3.2 & $425.0 \pm 8.5$ \\
\hline SMT-11 & 1378 & 231 & 0.17 & 683 & 0.05 & 0.577 & 2.0 & 0.2778 & 0.37 & $2935 \pm 47$ \\
\hline SMT-12 & 381 & 235 & 0.64 & 23.2 & 0.34 & 0.0705 & 2.1 & 0.0538 & 1.8 & $439.3 \pm 8.7$ \\
\hline SMT-13 & 1239 & 94 & 0.08 & 274 & 0.04 & 0.2570 & 2.0 & 0.0950 & 0.33 & $1475 \pm 26$ \\
\hline SMT-14 & 319 & 186 & 0.60 & 18.6 & 0.06 & 0.0680 & 2.1 & 0.0556 & 1.6 & $424.0 \pm 8.5$ \\
\hline SMT-15 & 296 & 163 & 0.57 & 17.9 & 1.01 & 0.0697 & 2.1 & 0.0533 & 3.5 & $434.3 \pm 8.8$ \\
\hline SMT-16 & 281 & 86 & 0.32 & 41.1 & 0.35 & 0.1697 & 2.0 & 0.1228 & 1.9 & $1011 \pm 19$ \\
\hline SMT-17 & 1211 & 296 & 0.25 & 451 & 0.06 & 0.4333 & 2.0 & 0.1634 & 0.30 & $2321 \pm 39$ \\
\hline \multicolumn{11}{|c|}{ Tonalite from Leigongshan } \\
\hline LGS-1 & 422 & 83 & 0.20 & 26.7 & 0.26 & 0.0735 & 2.0 & 0.0552 & 2.0 & $456.9 \pm 9.0$ \\
\hline LGS-2 & 898 & 330 & 0.38 & 55.2 & 0.12 & 0.0715 & 2.0 & 0.0549 & 1.1 & $445.3 \pm 8.7$ \\
\hline LGS-3 & 1313 & 592 & 0.47 & 81.8 & 0.10 & 0.0724 & 2.1 & 0.0549 & 0.88 & $450.9 \pm 8.9$ \\
\hline LGS-4 & 559 & 171 & 0.32 & 35.5 & 0.19 & 0.0737 & 2.0 & 0.0557 & 1.6 & $458.4 \pm 9.0$ \\
\hline LGS-5 & 395 & 91 & 0.24 & 25.3 & 0.35 & 0.0743 & 2.1 & 0.0548 & 2.5 & $462.2 \pm 9.2$ \\
\hline LGS-6 & 425 & 118 & 0.29 & 26.6 & 0.10 & 0.0729 & 2.0 & 0.0549 & 1.6 & $453.4 \pm 8.9$ \\
\hline LGS-7 & 1229 & 462 & 0.39 & 75.7 & 0.14 & 0.0716 & 2.1 & 0.0550 & 0.78 & $445.8 \pm 8.9$ \\
\hline LGS-8 & 588 & 202 & 0.35 & 37.0 & 0.21 & 0.0732 & 2.0 & 0.0555 & 1.4 & $455.2 \pm 8.9$ \\
\hline LGS-9 & 292 & 94 & 0.33 & 18.1 & 0.36 & 0.0716 & 2.1 & 0.0550 & 2.3 & $445.8 \pm 9.0$ \\
\hline LGS-10 & 1238 & 592 & 0.49 & 78.9 & 0.09 & 0.0741 & 2.0 & 0.0554 & 1.0 & $460.9 \pm 9.0$ \\
\hline
\end{tabular}

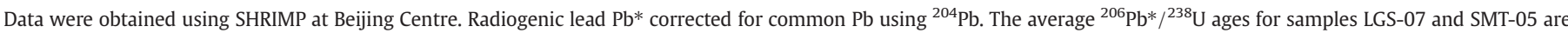

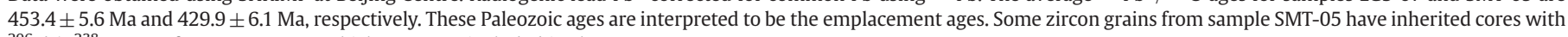
${ }^{206} \mathrm{~Pb}^{*} /{ }^{238} \mathrm{U}$ ages of $1011-2935 \mathrm{Ma}$, which were not included in the average age. 

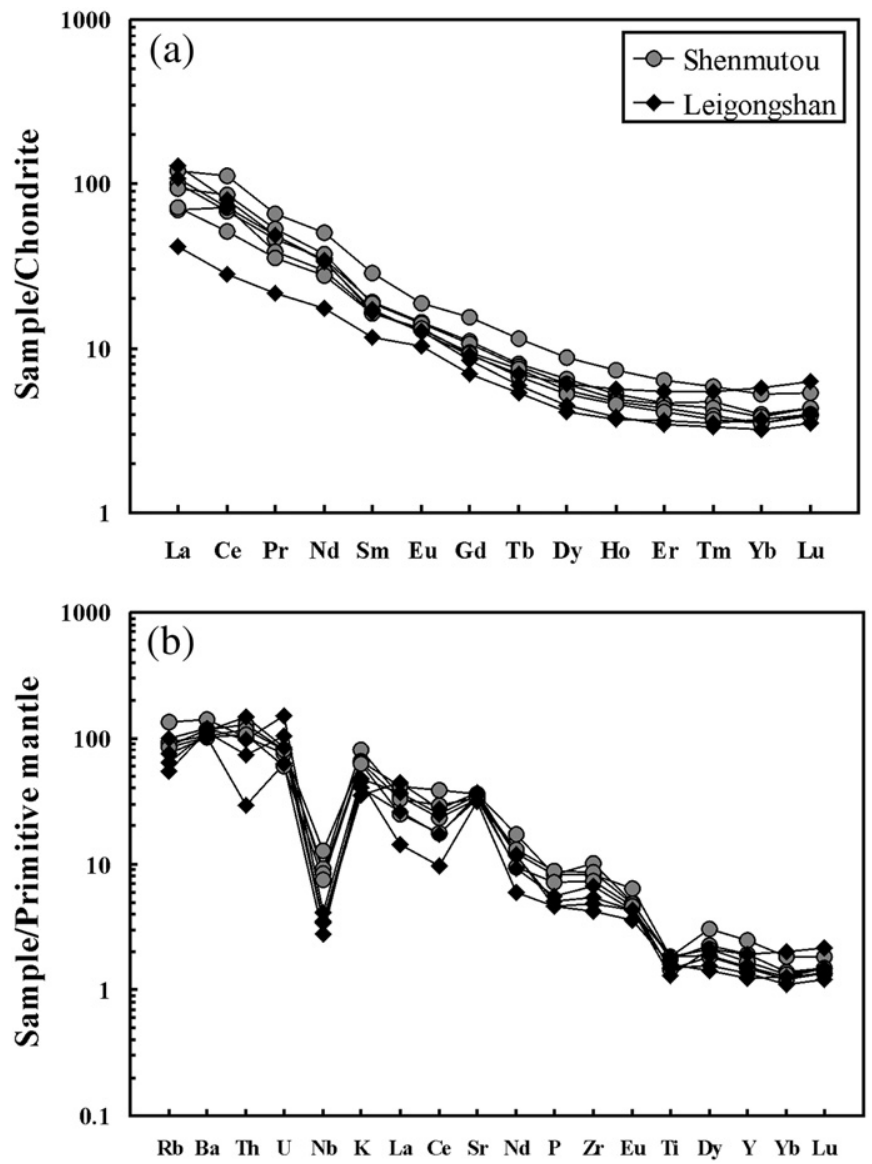

Fig. 2. (a) Plot of REE abundances normalized to the values of $C 1$ chondrite (Sun and McDonough, 1989), (b) Abundances of trace elements normalized to the values of primitive mantle (Sun and McDonough, 1989), then arranged in an order of increasing compatibility during melting of mantle peridotites.

was corrected for common $\mathrm{Pb}$ using measured ${ }^{204} \mathrm{~Pb}$. Zircon standard SL 13 (572 Ma, 238 ppm U) was used to calibrate U, Th and Pb concentrations of samples and TEMORA standard. Then, the TEMORA standard (417 Ma) was used to calibrate the $\mathrm{Pb} / \mathrm{U}$ and $\mathrm{UO} / \mathrm{U}$ values (Black et al., 2003). The ages of the analyzed zircons were calculated using SQUID and ISOPLOT program (Ludwig, 2000). Two sigma uncertainties are reported for the mean weighted ages (Table 3 ).

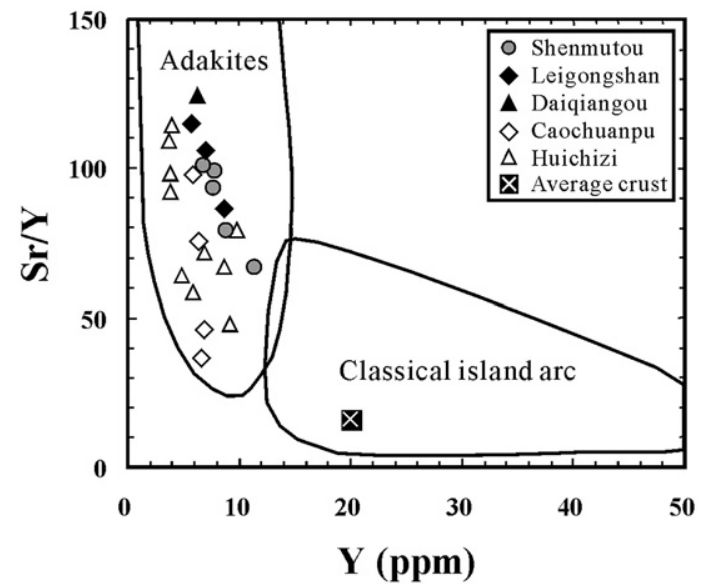

\section{Results}

The analyzed samples have $\mathrm{SiO}_{2}$ contents ranging from 62.6 to 68.4\%, high $\mathrm{Al}_{2} \mathrm{O}_{3}$ concentrations of $>15.9 \%$ and $\mathrm{K}_{2} \mathrm{O} / \mathrm{Na}_{2} \mathrm{O}$ ratios $<0.5$ (Table 1). Their $\left[\mathrm{Al}_{2} \mathrm{O}_{3} /\left(\mathrm{CaO}+\mathrm{Na}_{2} \mathrm{O}+\mathrm{K}_{2} \mathrm{O}\right)\right]$ ratios are $<1.10$ indicating magmatic origin, except for the high value of 1.28 for sample LGS15 , which is relatively enriched in secondary minerals and a high L.O.I. content. All the samples are characterized by LREE enrichments (Fig. 2a) with depletions in Nb and Ti (Fig. 2b). Most importantly, these granitoid samples are high in $\mathrm{Sr}(>654 \mathrm{ppm})$ and $\mathrm{La}(>9.8 \mathrm{ppm})$ with low $\mathrm{Y}(<11.3 \mathrm{ppm})$ and $\mathrm{Yb}(<0.98 \mathrm{ppm})$ abundances (Table 1$)$. Their high $\mathrm{Sr} / \mathrm{Y}$ of $>65$ and $(\mathrm{La} / \mathrm{Yb})_{\mathrm{N}}$ of $>11.2$ reflect the role of residual garnet and are characteristic of adakites (Defant and Drummond, 1990; Fig. 3). However, some of the analyzed samples have Mg\# lower than that of adakites ( $<42 \mathrm{vs.}>50$ ). In a strict sense, we refer our samples to as "adakitic rocks".

Most zircon grains exhibit well-developed crystal faces and magmatic oscillatory zoning (Fig. 4). Except for four data, the measured ${ }^{206} \mathrm{~Pb}^{*} /{ }^{238} \mathrm{U}$ ages vary within the range of 413-462 Ma with weighted averages of $453.4 \pm 5.6 \mathrm{Ma}(\mathrm{MSWD}=0.5)$ for the Leigongshan tonalite sample (RGS$07)$ and $429.9 \pm 6.1 \mathrm{Ma}(\mathrm{MSWD}=1.4)$ for the Shenmutou quartz monzonite sample (SMT-05) (Table 3). These ages represent the time of magma emplacement. The four older ages of 1011-2935 Ma were measured from cores of inherited zircon grains from sample SMT-05 (Table 3 ).

The bulk rocks have ${ }^{87} \mathrm{Sr} /{ }^{86} \mathrm{Sr}$ and ${ }^{143} \mathrm{Nd} /{ }^{144} \mathrm{Nd}$ ratios varying in the ranges of $0.70692-0.70834$ and $0.51228-0.51235$, respectively (Table 2 ). If the zircon emplacement ages and the measured $\mathrm{Rb} / \mathrm{Sr}$ and $\mathrm{Sm} / \mathrm{Nd}$ ratios are considered, the initial ${ }^{87} \mathrm{Sr} /{ }^{86} \mathrm{Sr}$ ratios are $0.70546-0.70677$ and the $\varepsilon_{\mathrm{Nd}}(t)$ values range from -1.4 to -1.9 (Table 2 ). Using the present-day $\left({ }^{147} \mathrm{Sm} /{ }^{144} \mathrm{Nd}\right)_{\mathrm{DM}}$ of 0.2137 and $\left({ }^{143} \mathrm{Nd} /{ }^{144} \mathrm{Nd}\right)_{\mathrm{DM}}$ of 0.51315 , the $T_{\mathrm{DM}}$ values were calculated to be $1.16-1.49 \mathrm{Ga}$ (Table 2 ).

\section{Petrogenesis of the Qilian adakitic rocks}

Both subducted oceanic slab and lower continental crust can be the sources for adakitic melts (e.g., Condie, 2005; Martin et al., 2005). The Qilian adakitic rocks have $\left({ }^{87} \mathrm{Sr} /{ }^{86} \mathrm{Sr}\right)_{\mathrm{i}}$ of $0.7055-0.7068$ and $\varepsilon_{\mathrm{Nd}}(t)$ values of -1.4 to -1.9 , which are more radiogenically enriched than that of mid-ocean-ridge basalt (MORB), consistent with derivation from lower continental crust rather than oceanic slab (Fig. 5). Although some segments of the subducting Chile ridge show crustal signatures due to source contamination (Klein and Karsten, 1995; Sturm et al., 1999), they are distinct from the Qilian adakitic rocks for higher $\varepsilon_{\mathrm{Nd}}(t)$ and lower $\left({ }^{87} \mathrm{Sr} /{ }^{86} \mathrm{Sr}\right)_{\mathrm{i}}$ values (Fig. 5). Moreover, the Qilian adakitic rocks have $\mathrm{Nb} / \mathrm{U}, \mathrm{Ce} / \mathrm{Pb}, \mathrm{Ti} / \mathrm{Eu}$, and $\mathrm{Nd} / \mathrm{Sm}$ ratios differing from that of

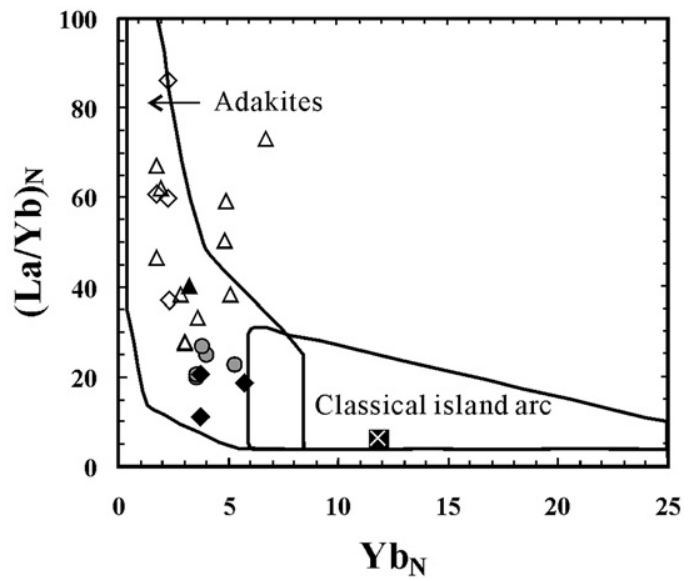

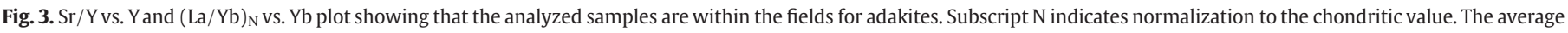

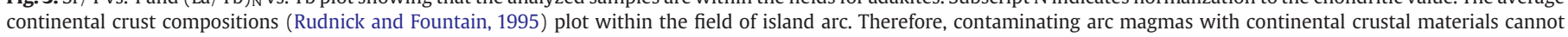
generate the low $\mathrm{Y}$ and $\mathrm{Yb}$ contents and high $\mathrm{La} / \mathrm{Yb}$ and $\mathrm{Sr} / \mathrm{Y}$ ratios of the adakitic rocks. 

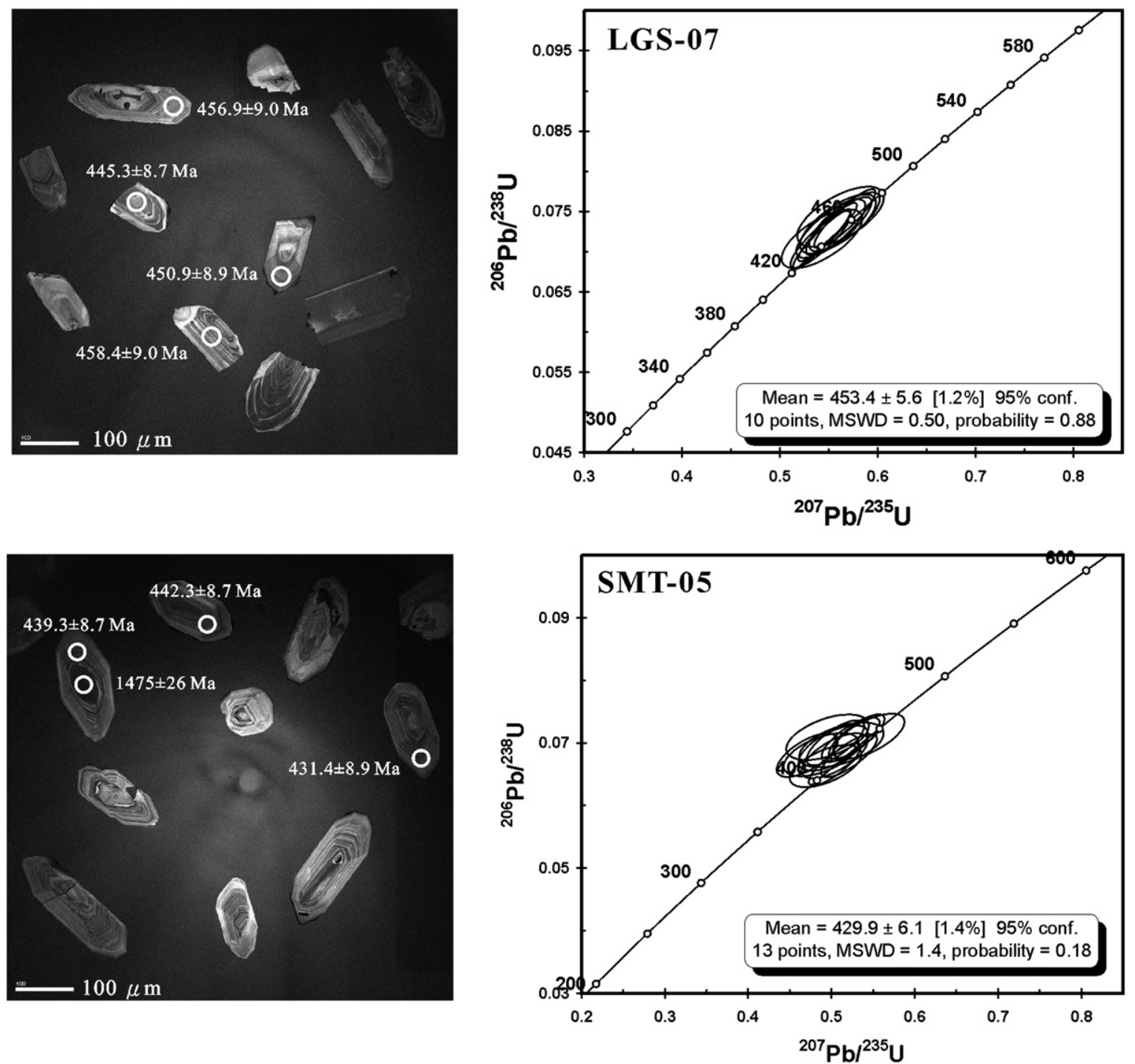

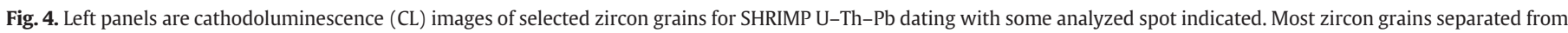

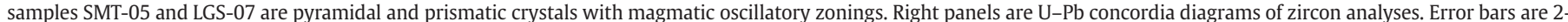
sigma errors (at 95\% confidence level).

these source-contaminated ocean ridges but resembling the crustal values (Fig. 6), further strengthening their continental affinity.

Although all the samples have similar trace element abundances and $\mathrm{Sr}$ and $\mathrm{Nd}$ isotope ratios, they are discernible in some other compositional parameters. Specifically, the Shenmutou samples have higher $\mathrm{MgO}, \mathrm{SiO}_{2}, \mathrm{Na}_{2} \mathrm{O}, \mathrm{Cr}$, and $\mathrm{Ni}$ contents than the Leigongshan and Daiqiangou samples (Table 1). Were these differences caused by fractional crystallization as postulated for lavas from the Negros arc of the Philippines (Solidum et al., 2003)? If so, the evolved melts should contain low $\mathrm{MgO}$ contents for amphibole and biotite removal and low $\mathrm{Sr}$ contents for feldspar removal. However, Sr contents of the low $\mathrm{MgO}$ and high $\mathrm{MgO}$ samples are comparable (Table 1), inconsistent with the control of fractional crystallization.

Compositions of experimental melts provide constraints on the petrogenesis of the Qilian adakitic rocks. In the $\mathrm{MgO}-\mathrm{SiO}_{2}$ plot, the Leigongshan and Daiqiangou samples plot within the field of partial melts from eclogites, typical of adakitic rocks derived from thickened lower crust (Fig. 7). In contrast, the Shenmutou samples deviate from the experimental melts to higher $\mathrm{MgO}$ at a given $\mathrm{SiO}_{2}$ content falling within the field for slab-derived adakites (Fig. 7). The high $\mathrm{MgO}$, Ni and $\mathrm{Cr}$ contents in slab-derived adakites relative to that of experimental melts have been attributed to interaction with mantle peridotite upon ascent (e.g., Condie, 2005; Martin et al., 2005). Applying this interpretation to the Shenmutou samples requires migrating shallow crustal melts through deep mantle peridotite. This apparent contradiction can be resolved by invoking lower crust delamination. At converging margins, the overlying continental crust was thickened by compression from subducted slab. As the lower mafic crust was metamorphosed to eclogites, it became denser and could be detached from crust, sinking into the mantle regime. In response to increases in pressure and temperature, the delaminated eclogites were then partially melted, generating adakitic melts (Kay and Kay, 1993). Upon ascent, the adakitic melts interacted with mantle peridotites, resulting in higher $\mathrm{MgO}, \mathrm{Ni}$ and $\mathrm{Cr}$ contents. The Shenmutou samples do plot within the field for adakitic rocks derived from delaminated lower crust in the $\mathrm{MgO}-\mathrm{SiO}_{2}$ plot (Fig. 7) and their $\mathrm{Ni}$ and $\mathrm{Cr}$ contents are comparable to the slab-derived adakites ( $\geq 20$ and 50 , respectively; Condie, 2005). Deviation from delaminated lower crust, however, cannot explain the high $\mathrm{SiO}_{2}$ and $\mathrm{Na}_{2} \mathrm{O}$ contents in the Shenmutou samples relative to that of the Leigongshan and Daiqiangou samples. Such differences were also shown by the comparison between the tonalites and granites from the Cordillera Blanca batholith, Peru, and were attributed to distinct sources (Petford and Atherton, 1996).

The proposed petrogenetic model for the Qilian adakitic rocks can be justified by geochronological data. The occurrence of ophiolites, 


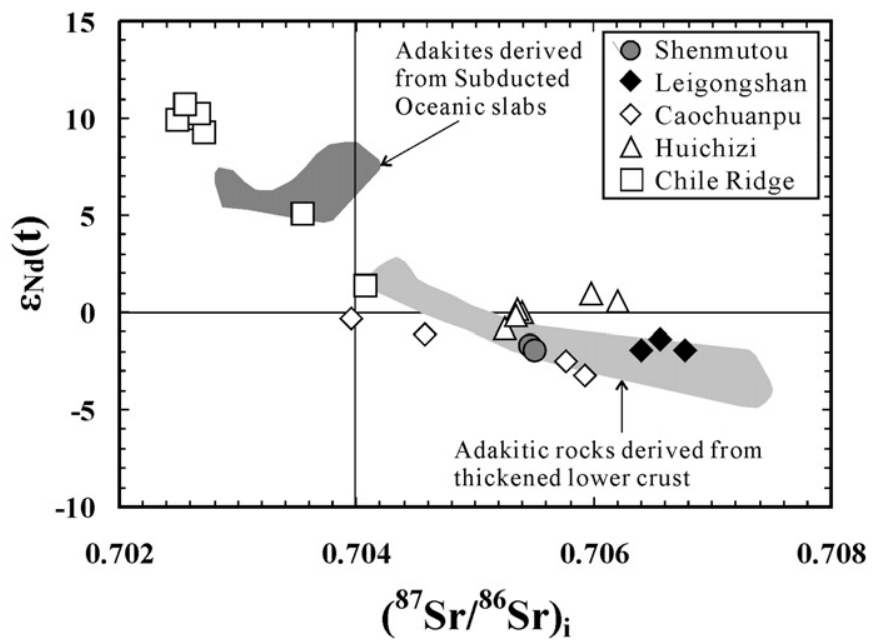

Fig. 5. $\left({ }^{87} \mathrm{Sr} /{ }^{86} \mathrm{Sr}\right)_{\mathrm{i}}$ vs. $\varepsilon_{\mathrm{Nd}}(t)$ plot comparing the Qilian and Qinling adakitic rocks with other adakitic rocks derived from subducted oceanic slab (data sources: Defant et al., 1992; Kay et al., 1993; Sajona et al., 2000) and continental lower crust (data sources: Muir et al., 1995; Petford and Atherton, 1996; Topuz et al., 2005; Wang et al., 2005b; Wen et al., 2008). Subscript i indicates initial ratio. " $t$ " indicates emplacement ages and values for the Qilian and Qinling samples are described in the text, whereas those for others are in the "data sources".

oceanic basalts and eclogites in the North Qilian orogenic belt indicates the existence of Paleo-Qilian ocean (Song et al., 2006). These ophiolites and oceanic basalts represent the $\sim 490-550$ Ma Qilian oceanic crust (Shi et al., 2004; Tseng et al., 2007), which subducted to the eclogite stability field at $\sim 460 \mathrm{Ma}$ (Song et al., 2006). Subsequently, the adakitic melts were generated during $\sim 430-450$ Ma (Table 3; Fig. 4). This evolutionary sequence is consistent with deriving adakitic melts from lower crust thickened by subduction-related compression. If the overriding lower crust extended to the depths where its adjacent subducted slab dehydrated, the slab-derived fluids could migrate to the lower crust to trigger melting (Wang et al., 2005b). Alternatively, heat for lower crust melting could be provided by underplating of earlier ( $450 \mathrm{Ma}$ ) mantle-derived arc magmas (Wang et al., 2005a).

Being the source of the adakitic magmas, the lower crust must be mafic and deeper than the eclogitic stability field, $>40 \mathrm{~km}$ (Rapp and Watson, 1995; Petford and Atherton, 1996). The present-day lower crust beneath the eastern Qilian area does extend to the depth of $\sim 45 \mathrm{~km}$ but is composed of andesitic layers (Liu et al., 2006), apparently inconsistent with the requirement of mafic sources. However, it should be noted that the present-day crustal thickness and constituent lithologies do not reflect that in the Paleozoic time.

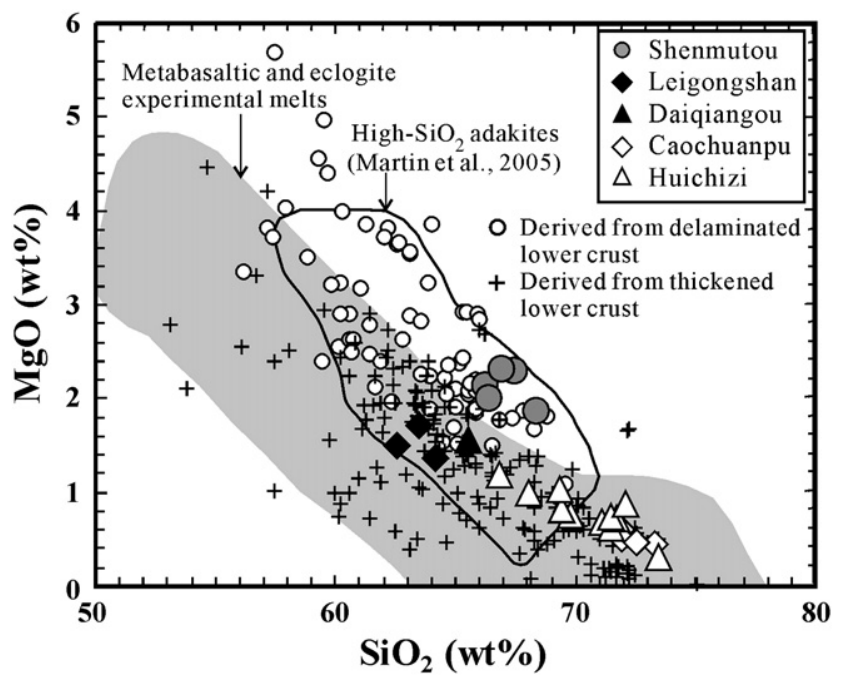

Fig. 7. $\mathrm{MgO}$ vs. $\mathrm{SiO}_{2}$ plot comparing adakitic rocks from the Qilian and Qinling orogenic belts and those proposed to derive from delaminated continental lower crust (Xu et al., 2002; Gao et al., 2004; Wang et al., 2004a,b; Guo et al., 2005; Wang et al., 2005b; Hou et al., 2007; Huang et al., 2008) and thickened continental lower continental crust (Smith and Leeman, 1987; Muir et al., 1995; Petford and Atherton, 1996; Johnson et al., 1997; Wareham et al., 1997; Yumul et al., 2000; Xiong et al., 2003; Chung et al., 2003; Topuz et al., 2005; Zhang et al., 2006; Wen et al., 2008). Also shown are the fields for natural high- $\mathrm{SiO}_{2}$ adakites and experimental melts produced from partial melting of eclogites (Martin et al., 2005).

Also, the mafic layers, if once existed, might have been delaminated into mantle. Although such a scenario can explain the genesis of the Qilian adakitic rocks, whether single or multiple thickening and delamination event(s) occurred since Early Paleozoic time remains to be constrained.

\section{Tectonic continuity between the Qilian and Qinling orogens}

Prior to our discovery of the Qilian adakitic rocks, Li et al. (1998, 2001 ) reported $437 \mathrm{Ma}$ adakitic rocks with $T_{\mathrm{DM}}$ ages of 1.0-1.1 Ga from Huichizi in the North Qinling orogenic belt, which is on the southeast of the North Qilian orogenic belt (Fig. 1a). In addition, Zhang et al. (2006) found $434 \mathrm{Ma}$ adakitic rocks with $T_{\mathrm{DM}}$ ages of 1.1-1.3 Ga from Caochuanpu at the boundary of Qilian and Qinling orogenic belts. These emplacement and model ages resemble that of the Qilian adakitic rocks (Tables 2 and 3). The Huichizi and Caochuanpu adakitic rocks also have $\mathrm{Sr}$ and $\mathrm{Nd}$ isotopic ratios indicating lower crust origin (Fig. 5). As the Leigongshan and Daiqiangou samples, the Huichizi and Caochuanpu adakitic rocks are compositionally comparable to
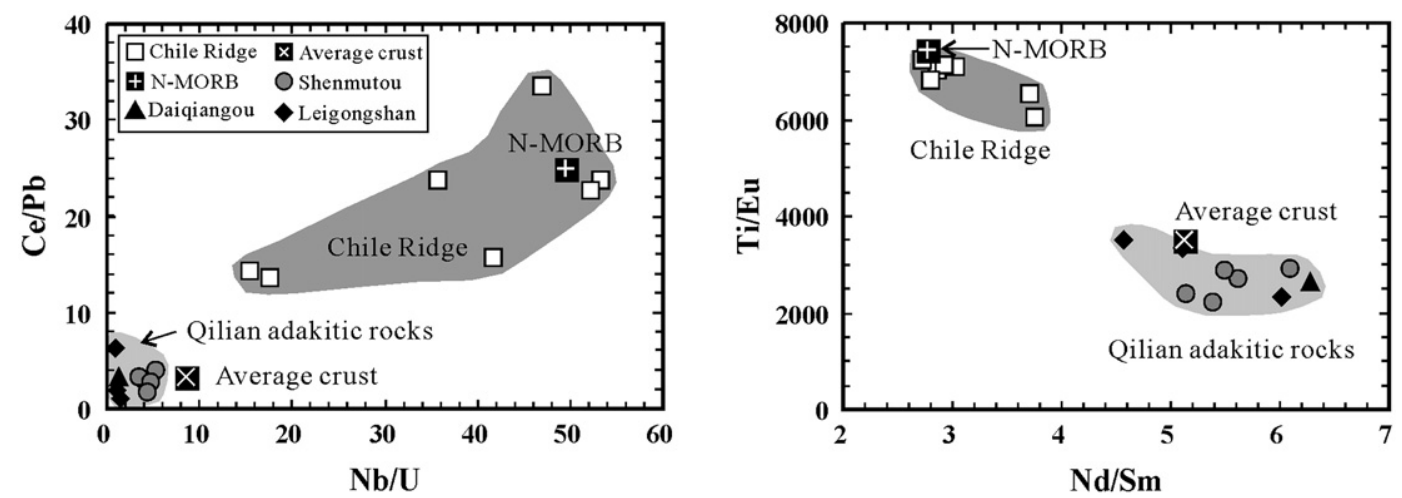

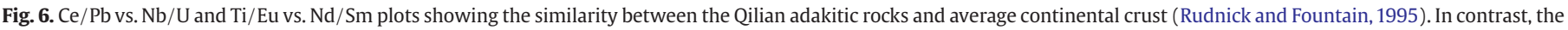

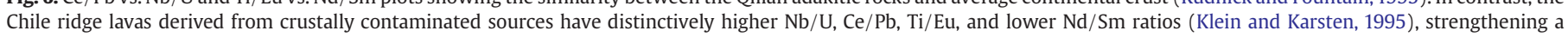
continental affinity of the Qilian adakitic rocks. 
experimental melts with low $\mathrm{MgO}, \mathrm{Ni}$, and $\mathrm{Cr}$ abundances, precluding interaction with peridotites (Fig. 7). The petrogenetical similarities between the Qilian and Qinling adakitic rocks suggest that these two orogenic belts, even the two larger scale mountain systems, were subjected to similar tectonomagmatic processes during Early Paleozoic time. This inference is supported by the general similarities in their tectonic configurations and lithological assemblages. Specifically, the Qilian and Qinling Mountain Systems were both formed by northward subduction of oceanic lithospheres. They are both divided into northern and southern parts by narrow ophiolitic belts (Fig. 1a), which had active margins on the north and passive margins on the south during Early Paleozoic time (Meng and Zhang, 2000; Zhang et al., 2001; Yang et al., 2002). The southern parts of these two mountain systems consist of Precambrian basement overlain by Paleozoic sedimentary-volcanic sequence (Zhang et al., 2001; Song et al., 2006). The northern parts known as the North Qilian and North Qinling orogenic belts are characterized by the occurrence of strongly deformed and slightly-moderately metamorphosed volcanic-sedimentary sequences together with mafic-ultramafic complexes, intermediate-felsic plutons, Precambrian basements and the 700-800 Ma granitoid fragments (Zhang et al., 2001; Ratschbacher et al., 2003; Wang et al., 2005a; Chen et al., 2006; Tseng et al., 2006). In summary, the overall consistencies in tectonic configurations and constituent lithological assemblages with the occurrence of adakitic rocks of similar ages and petrogenesis are an unlikely coincidence but suggest the continuity between eastern Qilian and western Qinling forming a $>1000 \mathrm{~km}$ Early Paleozoic orogenic belt. The apparent topographic discontinuity between these two orogenic belts might reflect later $(<420 \mathrm{Ma})$ tectonic activities.

The developments of the Qilian and Qinling orogens were closely related to the subduction of ancient oceanic lithospheres. Although the existence of the Paleo-Qilian and Qinling oceans has long been recognized, the tectonic architectures of these ocean basins have been debated. Xia et al. (1996) suggested that the Qilian ocean was a small oceanic basin, while Zhang et al. (1997) argued that it was a matured large ocean, probably comparable to the modern West Pacific. Following the recognition of the continuity between the Qilian and Qinling orogens, it is inferred that the adjacent $\sim 500 \mathrm{Ma}$ Qilian and Qinling oceans (Shi et al., 2004; Pei et al., 2005; Tseng et al., 2007) were parts of a large ocean basin rather than two separated small ones. This inference is consistent with paleontological evidence. Cambrian-Ordovician fossil biota from the North Qilian orogenic belt contain coral and trilobite specimens from North China, South China, North America, Siberian, Baltic Sea, and Australia (Zhou et al., 1996). The occurrence of southern continent specimens implies that the inferred $\sim 500 \mathrm{Ma}$ large ocean might correspond to the "Proto-Tethyan Ocean" that separated several small continents in the north from the larger Gondwana continent in the south. While we propose that the North Qilian and North Qinling orogenic belts were an un-divided tectonic unit during $\sim 550-430 \mathrm{Ma}$, it is emphasized that post 400 Ma volcanic rocks occur in the North Qinling orogenic belt but are absent in the North Qilian orogenic belt. Apparently, these two orogenic belts underwent distinct evolution history since the closure of the Proto-Tethyan Ocean ( $420 \mathrm{Ma}$; Stampfli and Borel, 2002).

\section{Acknowledgments}

We thank Y.S. Wan for SHRIMP analyses and L.Y. Huang for Sr and $\mathrm{Nd}$ isotope analyses. We also benefited from discussion with J.X. Zhang, K.A. Tung, and D.R. Wen. Critical reviews from W.J. Xiao and anonymous reviewer and editorial efforts from M. Santosh are appreciated. This research is supported by NSC grants, 89-2116-M006-03, 91-2116-M-006-16, and 92-2116-M-006-010 to H.-Y. Yang and 91-2116-M006-005 to H.-J. Yang.

\section{References}

Ayers, J.C., Dunkle, S., Gao, S., Miller, C.F., 2002. Constraints on timing of peak and retrograde metamorphism in the Dabie Shan ultrahigh-pressure metamorphic belt east-central China, using U-Th-Pb dating of zircon and monazite. Chemical Geology 186, 315-331.

Bian, Q.T., Li, D.H., Pospelov, I., Yin, L.M., Li, H.S., Zhao, D.S., Chang, C.F., Luo, X.Q., Gao, S.L., Astrakhantsev, O., Chamov, N., 2004. Age, geochemistry and tectonic setting of Buqingshan ophiolites, North Qinghai-Tibet Plateau, China. Journal of Asian Earth Sciences 23, 577-596.

Black, L.P., Kamo, S.L., Allen, C.M., Aleinikoff, J.N., Davis, D.W., Korsch, R.J., Foudoulis, C. 2003. TEMORA 1: a new zircon standard for Phanerozoic U-Pb geochronology. Chemical Geology 200, 155-170.

Chen, Z.H., Lu, S.N., Li, H.K., Li, H.M., Xiang, Z.Q., Zhou, H.Y., Song, B., 2006. Constraining the role of the Qinling orogen in the assembly and break-up of Rodinia: tectonic implications for Neoproterozoic granite occurrences. Journal of Asian Earth Sciences 28, 99-115.

Chung, S.-L., Liu, D., Ji, J., Chu, M.-F., Lee, H.-Y., Wen, D.-J., Lo, C.-H., Lee, T.-Y., Qian, Q. Zhang, Q., 2003. Adakites from continental collision zones: melting of thickened lower crust beneath southern Tibet. Geology 31, 1021-1024.

Condie, K.C., 2005. TTGs and adakites: are they both slab melts? Lithos 80, 33-44.

Defant, M.J., Drummond, M.S., 1990. Derivation of some modern arc magmas by melting of young subducted lithosphere. Nature 347, 662-665.

Defant, M.J., Jackson, T.E., Drummond, M.S., De Boer, J.Z., Bellon, H., Feigenson, M.D. 1992. The geochemistry of young volcanism throughout western Panama and southeastern Costa Rica: an overview. Journal of Geological Society of London 149, 569-579.

Gao, S., Rudnick, R.L., Yuan, H.-L., Liu, X.-M., Liu, Y.-S., Xu, W.-L., Ling, W.-L., Ayers, J., Wang, X.-C., Wang, Q.-H., 2004. Recycling lower continental crust in the North China craton. Nature 432, 892-897.

Guo, F., Fan, W.M., Li, C.W., 2005. Geochemistry of late Mesozoic adakites from the Sulu belt, eastern China: magma genesis and implications for crustal recycling beneath continental collisional orogens. Geological Magazine 142, 1-13.

Han, Y.G., Zhang, S.H., Pirajno, F., Wang, Y., Zhang, Y.H., 2009. New ${ }^{40} \mathrm{Ar}-{ }^{39} \mathrm{Ar}$ age constraints on the deformation along the Machaoying fault zone: implications for Early Cambrian tectonism in the North China Craton. Gondwana Research 16 255-263.

Hou, M.L., Jiang, Y.H., Jiang, S.Y., Ling, H.F., Zhao, K.D., 2007. Contrasting origins of late Mesozoic adakitic granitoids form the northwestern Jiaodong Peninsula, east China: implications for crustal thickening to delamination. Geological Magazine 144, 619-631.

Huang, F., Li, S.G., Dong, F., He, Y.S., Chen, F.K., 2008. High-Mg adakitic rocks in the Dabie orogen, central China: implications for foundering mechanism of lower continental crust. Chemical Geology 255, 1-13.

Johnson, K., Barnes, C.G., Miller, C.A., 1997. Petrology, geochemistry, and genesis of highAl tonalite and trondhjemites of the Cornucopia stock, Blue Mountains, Northeastern Oregon. Journal of Petrology 38, 1585-1611.

Johnson, D.M., Hooper, P.R., Conrey, R.M., 1999. XRF analysis of rocks and minerals for major and trace elements on a single low dilution Li-tetraborate fused bead. Advances in X-ray Analysis 41, 843-867.

Katsube, A., Hayasaka, Y., Santosh, M., Li, S.-Z., Terada, K., 2009. SHRIMP zircon U-Pb ages of eclogite and orthogneiss from Sulu ultrahigh-pressure zone in Yangkou area, eastern China. Gondwana Research 15, 168-177.

Kay, R.W., Kay, S.M., 1993. Delamination and delamination magmatism. Tectonophysics 219, 177-189.

Kay, S.M., Ramos, V.A., Marquez, Y.M., 1993. Evidence in Cerro Pampa volcanic rocks for slab-melting prior to ridge-trench collision in southern South America. Journal of Geology 101, 703-714.

Klein, E.M., Karsten, J.L., 1995. Ocean-ridge basalts with convergent-margin geochemical affinities from the Chile ridge. Nature 374, 52-57.

Li, W.P., Wang, T., Wang, X.X., Cao, H.F., 1998. Single zircon age of Huichizi granitoids complex in North Qinling. Regional Geology of China 19, 172-175 (in Chinese with English abstract).

Li, W.P., Wang, T., Wang, X., 2001. Source of Huichizi granitoid complex pluton in northern Qinling, central China: constrained in element and isotopic geochemistry. Earth Sciences-Journal of China University of Geosciences 26, 269-278 (in Chinese with English abstract).

Li, S.Z., Kusky, T.M., Wang, L., Zhang, G.W., Lai, S.C., Liu, X.C., Dong, S.W., Zhao, G.C., 2007 Collision leading to multiple-stage large-scale extrusion in the Qinling orogen: insights from the Mianlue suture. Gondwana Research 12, 121-143.

Liu, M., Mooney, W.D., Li, S., Okaya, N., Detweiler, S., 2006. Crustal structure of the northeastern margin of the Tibetan plateau from the Songpan-Ganzi terrane to the Ordos basin. Tectonophysics 420, 253-266.

Ludwig, K.R., 2000. Isoplot/Ex version 2.4. A geochronological toolkit for Microsoft Excel. Berkeley Geochron Centre Special Publication, pp. 1-56.

Martin, H., Smithies, R.H., Rapp, R., Moyen, J.-F., Champion, D., 2005. An overview of adakite, tonalite-trondhjemite-granodiorite (TTG), and sanukitiod: relationships and some implications for crustal evolution. Lithos 79, 1-24.

Meng, Q.R., Zhang, G.W., 2000. Geologic framework and tectonic evolution of the Qinling orogen, central China. Tectonophysics 323, 183-196.

Metcalfe, I., 2006. Palaeozoic and Mesozoic tectonic evolution and Palaeogeography of East Asia crustal fragments: the Korean Peninsula in context. Gondwana Research 9, 24-46.

Muir, R.J., Weaver, S.D., Bradshaw, J.D., Eby, G.N., Evans, J.A., 1995. Geochemistry of the Cretaceous Separation Point Batholith, New Zealand: granitoid magmas formed by melting of mafic lithosphere. Journal of Geological Society of London 152, 689-701. 
Pei, X.Z., Li, Y., Lu, S.N., Chen, Z.H., Ding, S.P., Hu, B., Li, Z.C., Liu, H.B., 2005. Zircon U-Pb ages of the Guanzizhen intermediate-basic igneous complex in Tianshui, West Qinling, and their geological significance. Geology Bulletin of China 24, 23-29 (in Chinese with English abstract).

Petford, N., Atherton, M.P., 1996. Na-rich partial melts from newly underplated basaltic crust: the Cordillera Blanca Batholith, Peru. Journal of Petrology 37, 1491-1521.

Rapp, R.P., Watson, E.B., 1995. Dehydration melting of metabasalt at 8-32 kbar: implications for continental growth and crust-mantle recycling. Journal of Petrology 36, 891-931.

Ratschbacher, L., Hacker, B.R., Calvert, A., Webb, L.E., Grimmer, J.C., McWilliams, M.O., Ireland, T., Dong, S., Hu, J., 2003. Tectonics of the Qinling (Central China): tectonostratigraphy, geochronology, and deformation history. Tectonophysics 366, 1-53.

Rudnick, R.L., Fountain, D.M., 1995. Nature and compositions of the continental crust: a lower crustal perspective. Reviews of Geophysics 33, 267-309.

Sajona, F.G., Naury, R.C., Pubellier, M., Leterrier, J., Bellon, H., Cotton, J., 2000. Magmatic source enrichment by slab-derived melts in a young post-collision setting, central Mindanao (Philippines). Lithos 54, 173-206.

Shi, R.D., Yang, J.S., Wu, C.L., Wooden, J., 2004. First SHRIMP dating for the formation of Yushigou ophiolite in late Sinian, North Qilian Mountains. Acta Geological Sinica 78 649-657.

Smith, D.R., Leeman, W.P., 1987. Petrogenesis of Mount St. Helens dacitic magmas. Journal of Geophysical Research 92, 10313-10334.

Solidum, R.U., Castillo, P.R., Hawkins, J.W., 2003. Geochemistry of lavas from Negros arc, west central Philippines: insights into the contribution from the subducting slab. Geochemistry Geophysics Geosystem 4. doi:10.1029/2003GC000513.

Song, S.G., Zhang, L.F., Niu, Y.L., Su, L., Song, B., Liu, D.Y., 2006. Evolution from oceanic subduction to continental collision: a case study from the Northern Tibetan Plateau based on geochemical and geochronological data. Journal of Petrology 47, 435-455.

Stampfli, G.M. Borel, G.D., 2002. A plate tectonic model for the Paleozoic and Mesozoic constrained by dynamic plate boundaries and restored synthetic oceanic isochrons. Earth Planetary Science Letters 196, 17-33.

Sturm, M.E., Klein, E.M., Graham, D.W., Karsten, J., 1999. Age constraints on crusta recycling to the mantle beneath the southern Chile Ridge: $\mathrm{He}-\mathrm{Pb}-\mathrm{Sr}-\mathrm{Nd}$ isotope systematics. Journal of Geophysical Research 104, 5097-5114.

Sun, S.S., McDonough, W.F., 1989. Chemical and isotopic systematics of oceanic basalts: implications for mantle composition and processes. In: Saunders, A.D., Norry, M.J. (Eds.), Magmatism in the Ocean Basins. Geological Society, London, Special Publication, vol. 42. Blackwell, Oxford, pp. 313-346.

Topuz, G., Altherr, R., Schwarz, W.H., Siebel, W., Satir, M., Dokuz, A., 2005. Post-collisiona plutonism with adakite-like signatures: the Eocene Saraycik granodiorite (Eastern Pontides, Turkey). Contributions to Mineralogy and Petrology 150, 441-455.

Tseng, C.-Y., Yang, H.-Y., Wan, Y.S., Liu, D., Wen, D.-J., Lin, T.C., Tung, K.-A., 2006. Finding of Neoproterozoic (similar to $775 \mathrm{Ma}$ ) magmatism recorded in metamorphic complexes from the North Qilian orogen: evidence from SHRIMP zircon $\mathrm{U}-\mathrm{Pb}$ dating. Chinese Science Bulletin 51, 963-970.

Tseng, C.-Y., Yang, H.-J., Yang, H.-Y., Liu, D.-Y., Tsai, C.-L., Wu, H.-G., Zuo, G.-C., 2007. The Dongcaohe ophiolite from the North Qilian Mountains: a fossil oceanic crust of the Paleo-Qilian ocean. Chinese Science Bulletin 52, 2390-2401.

Tung, K.-A., Yang, H.-J., Yang, H.-Y., Liu, D., Zhang, J., Wan, Y., Tseng, C.-Y., 2007. SHRIMP $\mathrm{U}-\mathrm{Pb}$ geochronology of the zircons from the Precambrian basement of the Qilian block and its geological significances. Chinese Science Bulletin 19, 2687-2701.

Wang, T., Wang, X.X., Zhang, G.W., Pei, X.Z., Zhang, C.L., 2003. Remnants of a Neoproterozoic collisional orogenic belt in the core of the Phanerozoic Qinling orogenic belt (China). Gondwana Research 6, 699-710.

Wang, Q., Xu, J.F., Zhao, Z.H., Bao, Z.W., Xu, W., Xiong, X.L., 2004a. Cretaceous highpotassium intrusive rocks in the Yueshan-Hongzhen area of east China: adakites in an extensional tectonic regime within a continent. Geochemical Journal 38, 417-434.

Wang, Q., Zhao, Z.H., Bao, Z.W., Xu, J.F., Liu, W., Li, C.F., 2004b. Geochemistry and petrogenesis of the Tongshankou and Yinzu adakitic intrusive rocks and the associated porphyry copper-molybdenum mineralization in southeast Hubei, east China. Resource Geology 54,137-152.
Wang, C.Y., Zhang, Q., Qian, Q., Zhou, M.F., 2005a. Geochemistry of the Early Paleozoic Baiyin volcanic rocks (NW China): implications for the tectonic evolution of the North Qilian orogenic belt. Journal of Geology 113, 83-94.

Wang, Q., McDermott, F., Xu, J.-F., Bellon, H., Zhu, Y.-T., 2005b. Cenozoic K-rich adakitic volcanic rocks in the Hohxil area, northern Tibet: lower-crustal melting in an intracontinental setting. Geology 33, 465-468.

Wareham, C.D., Millar, I.L., Vaughan, A.P.M., 1997. The generation of sodic granitic magmas, western Palmer Land, Antarctic Peninsula. Contributions to Mineralogy and Petrology 128, 81-96.

Wen, D.R., Chung, S.L., Song, B., Iizuka, Y., Yang, H.J., Ji, J.Q., Liu, D.Y., Gallet, S., 2008. Late Cretaceous intrusions of adakitic geochemical characteristics, SE Tibet: petrogenesis and tectonic implications. Lithos 105, 1-11.

Willia m s, I.S., 1998. U-Th-Pb geochronology by ion microprobe. Review of Economic Geology 7, 1-35.

Xia, L.Q. Xia, Z.C., Xu, X.Y., 1996. The Petrogenesis of Marine Volcanic Rocks from the North Qilian Mountains. Geological Publishing House, Beijing, p. 153 (in Chinese).

Xiong, X.L., Li, X.H., Xu, J.F., Li, W.X., Zhao, Z.H., Wang, Q., 2003. Extremely high-Na adakite-like magmas derived from alkali-rich basaltic underplate: the Late Cretaceous Zhantang andesites in the Huichang Basin, SE China. Geochemical Journal 37, 233-252.

Xu, Z.Q., Xu, H.F., Zhang, J.X., Li, H.B., Zhu, Z.Z., Qu, J.C., Chen, D.Z., Chen, J.L., Yang, K.C., 1994. The Zoulangnanshan Caledonian subductive complex in the northern Qilian Mountains and its dynamics. Acta Geological Sinica 68, 1-15 (in Chinese with English abstract).

Xu, J.F., Shinjio, R., Defant, M.J., Wang, Q., Rapp, R.P., 2002. Origin of Mesozoic adakitic intrusive rocks in the Ningzhen area of east China: partial melting of delaminated lower continental crust? Geology 32, 1111-1114.

Yang, H.-Y., Wu, Y.-M., Wu, C., 2002. Petrology of an arc-oceanic crust contact zone in the Laohushan back-arc basin, the eastern section of the North Qilian Mountains, NW China. Acta Geological Sinica 76, 1-13.

Yang, J.S., Xu, Z.Q., Dobrzhinetskaya, L.F., Green, H.W., Pei, X.Z., Wu, C.L., Wooden, J.L., Zhang, J.X., Wan, Y.S., Li, H.B., 2003. Discovery of metamorphic diamonds in central China: an indication of a $>4000$-km-long zone of deep subduction resulting from multiple continental collisions. Terra Nova 15, 370-379.

Ye, H.M., Li, X.H., Li, Z.-X., Zhang, C.L., 2008. Age and origin of high Ba-Sr appinitegranites at the northwestern margin of the Tibet Plateau: implications for early Paleozoic tectonic evolution of the Western Kunlun orogenic belt. Gondwana Research 13, 126-138.

Yumul, G.P., Dimalanta, C.B., Bellon, H., Faustino, D.V., De Jesus, J.V., Tamayo, R.A., Jumawan, F.T., 2000. Adakitic lavas in the Central Luzon back-arc region, Philippines: lower crustal partial melting products? Island Arc 9, 499-512.

Zhai, M.G., Guo, J.H., Li, Z., Chen, D.Z., Peng, P., Li, T.S., Hou, Q.L., Fan, Q.C., 2007. Linking the Sulu UHP belt to the Korean Peninsula: evidence from eclogite, Precambrian basement, and Paleozoic sedimentary basin. Gondwana Research 12, 388-403.

Zhang, G.W., Zhang, B.R., Yuan, X.C., Xiao, Q.H., 2001. Qinling Orogenic Belt and Continental Dynamics. Science Press, Beijing, p. 855 (in Chinese).

Zhang, H.F., Zhang, B.R., Harris, N., Zhang, L., Chen, Y.L., Chen, N.S., Zhao, Z.D., 2006. U-Pb zircon SHRIMP ages, geochemical and $\mathrm{Sr}-\mathrm{Nd}$-Pb isotopic compositions of intrusive rocks from the Longshan-Tianshui area in the southeast corner of the Qilian orogenic belt, China: constraints on petrogenesis and tectonic affinity. Journal of Asian Earth Sciences 27, 751-764.

Zhang, Q., Sun, X.M., Zhou, D.J., Qian, Q., Chen, Y., Wang, Y.M., Jia, X.Q., Han, S., 1997. The Characteristics of north Qilian ophiolites, forming settings and their tectonic significance. Advance in Earth Sciences 12, 366-393 (in Chinese with English abstract).

Zhang, R.Y., Liou, J.G., Ernst, W.G., 2009. The Dabie-Sulu continental collision zone: A comprehensive review. Gondwana Research 16, 1-26.

Zhou, Z.Q. Cao, X.D., Zhao, J.T., Hu, Y.X., 1996. Early Palaeozoic stratigraphy and sedimentary-tectonic evolution in Eastern Qilian Mountains, China. Northwest Geoscience 17, 1-58 (in Chinese with English abstract). 